Fourteen days ago, when on the Fraser River, eighty miles from here, I saw after sunset a very brilliant aurora borealis. I write this thinking there may be a repetition of the phenomena in England, in which case this note may possess interest. G. W. Lamplugh

Victoria, Vancouver Island, October 13

\section{Peculiar Ice Forms}

THE ice structures observed by Mr. Woodd Smith (November 6, p. 5) are evidently the same as were described in vol. $x x i$. p. 396. I have often seen such fibrous masses since, under circumstances which left no doubt of their being mainly due to prolonged condensation of aqueous vapour from the air; the fibres, white like asbestos, and covered only by a very thin layer of earthy particles, rising from a hard subsoil. The absorption of aqueous vapour by the soil, especially on mountains, seems not yet to be duly appreciated, although it is proved by the many springs issuing at short distances below the summits, and has been insisted upon already in Er. Darwin's "Botan. Garden" and "Phytonomia" (chap. xi. 2). "Rainfall being the source of all water-supply" (NATURE, vol. xxx. p. 375) is a statemen hardly to be maintained.

Freiburg, Badenia, November 8

\section{Seismographs-An Apology}

I AM just in receipt of the inclosed letter from Mr. Charles A. Stevenson, in which he claims the original idea of the actuating mechanism in the horizontal component seismograph I have lately described in these pages, and he includes a copy of his paper to jnstify his remarks. I therefore think it my duty to offer my apologies to him for not having given him full credit for his invention so far as it goes, although I have unconsciously done him wrong. Naples is unfortunately very badly off for modern scientific works and Proceedings of Societies, both as regards the National and the University libraries, and as far as I know no copy of Mr. Stevenson's paper exists in the town, except the one he has now sent me.

Perhaps I may be permitted to point out that Mr. Stevenson's seismograph, so far as it is described, would be almost useless for the following reasons :-

(I) The inertia of the upper glass plate would be insufficient not to be affected by the slight movement conducted through the ivory balls to it. This is the reason I use the very heavy lead disk.

(2) No earthquake shock is perfectly horizontal, so that Mr. Stevenson's instrument would only be fit to register the horizontal component of the earth-wave, and would fail to do this, since if the angle of emergence was appreciable it would be jerked up off its supports, and consequently would simply register a series of interrupted lines. This is why I introduced the upper balls and resistance plate.

(3) If the instrument was disturbed by an earth-wave of large amplitude, the registering arm would pass beyond the border of the smoked plate (unless the apparatus was of very great dimensions, so failing to fulfil the conditions of the British Association), where the needle would drop out, or fall so low as to prevent the return of the arm over the plate.

(4) If the earthquake was of some seconds' duration and composed of many varying movements, as is generally if not always the case, a network of irregular curves would remain on the glass that would be quite unintelligible.

If a thing is to be done, it is advisable to do it well, and it is less possible to have accurate registers of earthquake shocks than of the force and direction of the wind, barometric pressure, or any other meteorological phenomena. The requirements of the British Association with regard to expense, size, and portability of seismographs, will not permit anything like an accurate investigation of geodynamics.

In conclusion, should I have overlooked and appropriated the ideas of any other inventor, I shall be happy to fully acknowledge them if sufficient evidence is given (as in the above case) of priority of publication.

November 7

H. J. JoHNSTON-LAvis

\section{Tovember 7}

45, Melville Street, Edinburgh, November 3

I NOTICED recently in NATURE (vol. xxx. p. 608) an article by you in which you describe a seismograph for recording earthquake shocks, which would appear to be your own invention from reading the paper. No doubt the method of making the record, springs, and upper balls are your own invention, but the principle on which the seismograph there described acts is, as far as I know, mine or my father's. I inclose the paper in which it was first described, and I would be glad to learn from you if you forestalled me.

Dr. Johnston-Lavis, Naples

\section{Fly-Maggots Feeding on Caterpillars}

A FEw months ago I had a caterpillar of Papilio erythronius, which I found on a lemon-trec. I put it into a card-box, and fed it daily on lemon-leaves. The box was covered with cloth tied tightly all round the opening. After some days, the caterpillar fixed itself to the side of the box, and turned into a chrysalis in the ustal way. One day on opening the box, instead of finding the chrysalis changing into its usual colours and markings, it was dark all over. A few days more, on reopening the box, I found six fully-developed cream-coloured maggots at the bottom of the box. I was rather puzzled to conjecture how these maggots got into a box three inches high, with a bit of cloth tied all round the opening. I put the maggots into a little box with some earth under a tumbler. They immediately buried themselves in the earth. In a few days I found six chrysalides, and some days later there were six ordinary houseflies buzzing within the tumbler. I then examined the dark chrysalis of the $P$. erythronius, which was evidently dead, and found it only a shell. All its interior had been consumed by the six maggots. It is evident that these maggots in their infant stage had already been in the body of the caterpillar when I boxed it. The latter had gone through its transformation as if nothing was the matter with it, although, if one could have interrogated it, probably it would have complained of mysterious gnawings and creepings in its interior. A time, of course, came when, for want of nerve-centres and other organs, the chrysalis could not go on with its development into the perfect Papilio. The six maggots having had a full meal, found their way out of the Papilio's chrysalis in order to undergo their transformation.

I knew that the larvæ of the Ichneumonidæe fed on the live bodies of caterpillars, but I did not know that the larvæ of the house-fly did so also.

Etawah, India, October 18

\section{THE CRYSTALLINE ROCKS OF THE SCOTTISH HIGHLANDS}

FVER since the discovery of Silurian fossils in the rocks of North-West Sutherland, it has been recognised that in that region lies the key to the structure of the Scottish Highlands. Accordingly, when in the progress of the Geological Survey, the mapping of the Highlands had to be undertaken, I determined that a detailed survey of the Sutherland ground on the scale of six inches to a mile should be made as a basis for the work. In the summer of last year a surveying party under the charge of Mr. B. N. Peach was stationed there, with instructions to begin by mapping the Durness Basin. This duty was satisfactorily accomplished before the end of the season. The Silurian series of Durness was ascertained to be about 2000 feet thick, and to consist of numerous successive zones, which were traced on the six-inch maps and discriminated in such a way as to be recognisable should they be found to occur in the more complicated region to the east. With this necessary groundwork well established, the Eriboll tract was attacked this summer by Messrs. Peach and Horne. I had never myself had an opportunity of studying the Eriboll sections, which, from the days of Macculloch down to the present time, have been such a fruitful subject of discussion. It was a special injunction to the officers now intrusted with the detailed survey of the region to divest themselves of any prepossessions in favour of published views and to map the actual facts in entire disregard of theory. By the close of this last season the structure of the Eriboll area had likewise been traced upon the six-inch maps, and $I$ then went north to inspect the work. From time 